\title{
Survey of Phaeomoniella chlamydospora in vineyard weeds
}

\author{
Pedro Siefer Raggio Vergaças ${ }^{1,2}$, Ana Beatriz Monteiro Ferreira ${ }^{1}$, Daniel Andrade de Siqueira Franco ${ }^{1}$, Luís Garrigós \\ Leite $^{1}$, Wagner Narciso Campos ${ }^{3}$, Ricardo Harakava ${ }^{3} \&$ César Júnior Bueno ${ }^{1}$
}

${ }^{1}$ Instituto Biológico / APTA. Alameda dos Vidoeiros, n. 1097, Bairro Gramado, CEP 13101-680, Campinas, São Paulo (SP), Brasil. ${ }^{2}$ Bolsista PIBIC-CNPq (Processos 103383/2015-8 e 138608/2015-6). ${ }^{3}$ Instituto Biológico / APTA. Avenida Conselheiro Rodrigues Alves, 1.252, Vila Mariana, CEP 04014-900, São Paulo, SP, Brasil.

Autor para correspondência: César Júnior Bueno (cjbueno@biologico.sp.gov.br)

Data de chegada: 17/05/2017. Aceito para publicação em: 29/08/2017.

$10.1590 / 0100-5405 / 180135$

\begin{abstract}
Vergaças, P.S.R.; Ferreira, A.B.M.; Franco, D.A.S.; Leite, L.G.; Campos, W.N.; Harakava, R.; Bueno, C.J. Survey of Phaeomoniella chlamydospora in vineyard weeds. Summa Phytopathologica, v.44, n.3, p.218-222, 2018.

Petri disease is serious, complex and difficult to control in vines worldwide. The main causal agent of this disease is the fungus Phaeomoniella chlamydospora. This fungus also occurs in the vineyard weed Convolvulus arvensis. In Brazil, this fungus was found only in grapevines. Thus, the aim of the present study was to carry out a phytosociological survey of weeds in an area with different vine rootstocks, as well as in a field of seedlings production, in an experimental area with vines and in different areas with commercial vineyards, besides verifying which weed species could be hosting the fungus P. chlamydospora. For the phytosociological survey of weeds, a square was randomly cast ten times at the site, followed by counting, identification and

sampling of all species. To verify host species of the fungus, vascular tissue of plants was isolated in culture media and DNA extraction from the same plant tissue was carried out followed by PCR with specific primers of the fungus for the elongation factor gene (Pchlamy-EF-F 5'-CTCATTATCACATTTTGCTGC-3' and Pchlamy-EF-R 5'-GAGAACAGTCAGTGATGAGC-3'). Considering all surveyed fields, 46 weed species were detected in 17 families, especially Asteraceae and Poaceae, which had the largest number of species. Using conventional or molecular methods, the fungus $P$. chlamydospora was not detected infecting weeds, which highlights that Petri disease occurs only in grapevines.
\end{abstract}

Keywords: trunk diseases, Vitis, inoculum sources

\section{RESUMO}

Vergaças, P.S.R.; Ferreira, A.B.M.; Franco, D.A.S.; Leite, L.G.; Campos, W.N.; Harakava, R.; Bueno, C.J. Levantamento de Phaeomoniella chlamydospora em plantas daninhas de vinhedo. Summa Phytopathologica, v.44, n.3, p.218-222, 2018.

A doença de Petri é grave, complexa e de difícil controle em videiras no mundo. O principal agente causal desta doença é o fungo Phaeomoniella chlamydospora. Este fungo ocorre também na planta daninha de vinhedo Convolvulus arvensis. No Brasil, este fungo foi encontrado somente em videiras. Assim, o objetivo do presente estudo foi efetuar um levantamento fitossociológico de plantas daninhas em uma área com diferentes cavalos de videiras, em um campo de produção de mudas, em uma área experimental com videira e em diferentes áreas com plantio comercial de videira e verificar quais espécies poderiam estar hospedando o fungo P. chlamydospora. Para o levantamento fitossociológico das plantas daninhas, lançava-se um quadrado ao acaso, por dez vezes, no local, contando, identificando e amostrando todas as espécies. Para verificar as espécies hospedeiras do fungo, realizou-se isolamento do tecido vascular das plantas em meios de cultura e extração de DNA do mesmo tecido vegetal seguido de PCR com primers específicos do fungo do gene do fator de elongação (Pchlamy-EF-F 5'-CTCATTATCACATTTTGCTGC-3' e Pchlamy-EF-R 5'-GAGAACAGTCAGTGATGAGC-3'). Em todo o levantamento, foram detectadas 46 espécies de plantas daninhas em 17 famílias, destacando-se as famílias Asteraceae e Poaceae com o maior número de espécies cada. Não foi detectado de maneira convencional e nem molecularmente o fungo $P$. chlamydospora infectando plantas daninhas, ressaltando a ocorrência da doença de Petri apenas em videiras.

\section{Palavras-chave: doenças de tronco, Vitis, fontes de inóculo}

Viticulture in Brazil is a major source of income for smallholders. Grapes are grown for juice and wine production, as well as for consumption in natura or as raisins. In addition, tourism has recently started developing around viticulture $(12,27)$.

Petri disease causes decline and dieback of grapevines, especially in young vines. It is a complex disease and therefore difficult to control. This disease is caused by a combination between Phaeomoniella chlamydospora (W. Gams, Crous, M. J. Wingf \& L. Mugnai Crous \& W. Gams) and several Phaeoacremonium species. Recently, Cadophora lutea-olivaceae (F. H. Beyma) Harrington \& McNew was reported as another fungus that can contribute to Petri disease in young vineyards $(22,23,25,29,30)$. Meanwhile, $P$. chlamydospora is more often associated with typical symptoms of Petri disease, causing the largest lesions and being more frequently re-isolated, compared to other fungi related to this disease $(25,30)$. Other genera of fungi that have contributed to decline in young vineyards are Acremonium and Phialemoniopsis, such as the species Phialemoniopsis curvata (= Phialemonium curvatum) $(24,25,32$,). Halleen et al. (25) reported that the relative importance of these fungi to decline or Petri disease was uncertain and needed to be confirmed with additional studies. 
External symptoms of Petri disease are late budbreak, stunted shoot growth, reduced vegetative vigor, shortened internodes, lower stem diameter, interveinal chlorosis foliage with necrotic margins, premature defoliation, wilting and dieback. Internal symptoms (xylem vessel) of the trunk are black spots and black streaking, tyloses and black gums $(5,19,29,30,36)$.

Petri disease has been reported in different parts of the world where grapevine is cultivated $(16,21)$. In Brazil, Petri disease fungi were found in Rio Grande do $\operatorname{Sul}(3,20)$, as well as in the northeast region of the country (10). In São Paulo State, the phytopathogens P. chlamydospora and Phaeoacremonium minimum ( $=$ P. aleophillum) were detected in young vineyards of the variety 'Niagara Rosada' (17).

Isolation of the causal agents of Petri disease is not easy. Morphological and cultural characterization of the fungi on the culture medium is used for identification but constitutes a difficult and long process $(5,33)$. The complete diagnosis can extend up to four weeks, showing the need for a more rapid and more sensitive method such as molecular biology $(8,33)$.

Inoculum sources of Petri disease fungi are infected vegetative propagation materials, propagation processes of grapevine plants, infested soil, and aerial inoculum $(6,29)$. In the soil, P. chlamydospora spores can act as potential inoculum to infect young plants of vine (35) and also of weeds (13).

Without the host plant, the phytopathogens can survive in any other host such as commercial plants or weeds $(4,9)$. According to Pitelli (34), weeds are those plants that emerge spontaneously in agricultural crops, interfering in the productivity and in the production systems. These plants have the capacity to produce a large number of seeds and to present dormancy and uneven germination. Chaves et al. (9) reported that weeds can be alternative hosts of phytopathogens and potential inoculum sources of the pathogens, guaranteeing their survival and interfering with the epidemiology of diseases.

Agustí-Brisach et al. (2) found in Spain some weeds as alternative hosts for the pathogens of black foot and Petri disease in grapevine rootstock mother fields, open-root field nurseries, and commercial vineyards. These weeds serve as additional inoculum source to infect vines.

No phytosociological survey of vineyard weeds was carried out in Brazil and there was no detection of $P$. chlamydospora in vineyard weeds. Thus, the aims of the current study were: 1) to carry out a phytosociological survey of vineyard weeds found in commercial vine fields of 'Niagara Rosada' plants, in a field of grapevine seedlings production, in an experimental area and in a locality with germplasm of grapevine rootstocks; and 2) to verify if vineyard weeds are infected with P. chlamydospora, using conventional and molecular diagnosis.

\section{MATERIAL AND METHODS}

Phytosociological survey of vineyard weeds in different fields Commercial vineyards ('Niagara Rosada' variety) visited in São Paulo State - Brazil, and their respective sampling periods were: Louveira (S: $23^{\circ} 03.916^{\prime}$ and $\mathrm{W}$ : $046^{\circ}$ 55.639') - October/2014; Vinhedo (S: $23^{\circ} 02.430^{\prime}$ and W: $\left.046^{\circ} 58.886^{\prime}\right)$ - October/2014; Jundiaí (S: $23^{\circ} 07.830^{\prime}$ and W: $\left.046^{\circ} 56.853^{\prime}\right)$ - November/2015; Jarinu (S: $23^{\circ} 07.761^{\prime}$ and $\mathrm{W}$ : $046^{\circ} 40.951^{\prime}$ ) - January/2015; Porto Feliz (S: $23^{\circ} 17.546^{\prime}$ and W: $\left.047^{\circ} 28.252^{\prime}\right)$ - February/2015; São Miguel Arcanjo (S: $23^{\circ} 49.750^{\prime}$ and $\left.\mathrm{W}: 047^{\circ} 59.008^{\prime}\right)-\mathrm{March} / 2015$, and Jales (S: $20^{\circ} 12.376^{\prime}$ and W: $\left.050^{\circ} 36.190^{\prime}\right)$ - May/2015. The fungus
P. chlamydospora was reported in 'Niagara Rosada' plants in almost all these locations (17).

The variety 'Niagara Rosada' is the result of a somatic mutation in 'Niagara Branca' (Vitis labrusca L. x Vitis vinifera L.), which occurred in 1933 in Louveira, São Paulo State, Brazil, and nowadays predominates over 'Niagara Branca' (38).

Seedlings production field located in São Bento de Sapucaí, São Paulo State, Brazil (S: $22^{\circ} 40.963^{\prime}$ and W: 45 44.676') was visited in February/2016. The experimental area of vines is located in the Viticulture and Enology Station of the Agricultural Research Company of Minas Gerais (EPAMIG), Caldas City, Minas Gerais State, Brazil (S: $21^{\circ} 55.092$ ' and $\left.\mathrm{W}: 46^{\circ} 23.007^{\prime}\right)$, visited in March/2016. The germplasm of grapevine rootstocks is located in the Fruit Station of the Agronomic Institute of Campinas (IAC), Jundiaí City, São Paulo State, Brazil (S: $23^{\circ} 06.718^{\prime}$ and $\mathrm{W}: 46^{\circ} 55.949^{\prime}$ ), visited in April/2016.

The vineyard weeds were sampled by using the inventory square method (7), which consists of a $0.5 \times 0.5 \mathrm{~m}$ square that is randomly cast ten times in the study area. The weed species found inside each square were counted and identified visually or based on specific manuals and grouped into families. After each casting, six weed species were collected for diagnosis of the fungus $P$. chlamydospora.

Symptoms and signals of general disease in the aerial part and in the xylem vessels of each sampled weed species were sought and recorded.

\section{Detection of $P$. chlamydospora in vineyard weeds \\ Conventional method}

Fragments of $40 \mathrm{~mm}$ length of xylem vessels were collected from the collard region of three plants of each vineyard weed species found in the fields (2). These fragments were superficially disinfected by immersion for 30 seconds in $70 \%$ alcohol and $1 \mathrm{~min}$ in a $1.5 \%$ solution of sodium hypochlorite followed by immersion in sterile distilled water. Then, the fragments were dried on sterile filter paper, cut into smaller fragments $(5 \mathrm{~mm})$ with a sterile scalp, mixed, and plated at random on two different culture media: potato dextrose agar (PDA) and water agar. After incubation for seven days, the colonies that grew in water agar medium were peeled onto plates containing PDA. All plates were incubated in a growth chamber under $23^{\circ} \mathrm{C}$ and $12 \mathrm{~h}$ photoperiod for 21 days $(3,16)$. The percentages of fragments with $P$. chlamydospora (11) were calculated for each plate.

Experimental design was completely randomized in factorial scheme which contained weed species per locality, the culture media and eight replicates. Each replicate was a Petri plate with the culture medium containing four plated fragments, totaling 64 fragments.

\section{Molecular method}

The technique used for molecular diagnosis of P. chlamydospora isolated directly from vineyard weeds was polymerase chain reaction (PCR) with specific primers for this fungus.

The DNA of vineyard weeds was extracted according CTAB method (14) of tissues removed from the xylem vessels of the collard region of three plants of each species (2). PCR was performed with $1 \mu \mathrm{L}$ DNA extracted from weeds ( 100 ng), 2U GoTaq DNA polymerase (Promega), $200 \mathrm{nM}$ each primer, $200 \mathrm{uM}$ dNTPs, GoTaq Green Cap in a final volume of $25 \mathrm{uL}$. The protocol of the thermocycler program was: initial denaturation at $94^{\circ} \mathrm{C} / 2 \mathrm{~min}, 40$ cycles of $94^{\circ} \mathrm{C} / 10 \mathrm{~s}-56^{\circ} \mathrm{C} / 30$ $\mathrm{s}-72^{\circ} \mathrm{C} / 30 \mathrm{~s}$, and final extension at $72^{\circ} \mathrm{C} / 4 \mathrm{~min}$. The amplification of products was verified in agarose gel stained with ethidium bromide and observed under UV light. Positive control was the fungus $P$. chlamydospora. 
The specific primers developed in the current study and used to amplify the gene encoding the 1-alpha elongation factor of the fungus $P$. chlamydospora were Pchlamy-EF-F 5'-CTCATTATCACATTTTGCTGC-3' and Pchlamy-EF-R 5'-GAGAACAGTCAGTGATGAGC-3'. The amplified product size was $161 \mathrm{bp}$.

The mentioned methodology was previously tested in 'Niagara Rosada' grapevine plants inoculated or not with P. chlamydospora. The molecular diagnosis of the fungus in the infected plants was successful and no amplification of the fungus was verified in the control plants (Unpublished data).

\section{RESULTS AND DISCUSSION}

In the current study, a total of 46 vineyard weed species were found in the visited fields (Table 1), which belong to 17 families, especially Asteraceae and Poaceae, both of which grouped the largest number of species. In a phytosociological survey of vineyard weeds in Croatia conducted by Dujmović-Purgar \& Hulina (15), the most common weeds belonged to the families Asteraceae and Poaceae. In Dão winegrowing region of Portugal, the most commonly found weeds also belonged to the families Asteraceae and Poaceae, besides Fabaceae (28).

The fungus $P$. chlamydospora was not detected based on conventional and molecular diagnosis in any weeds sampled in the vineyard or related fields visited in the current study (Table 1). Differently, in Spain, Agustí-Brisach et al. (2) visited grapevine rootstock mother fields, open-root field nurseries and commercial vineyards and found some vineyard weeds infected with black foot and Petri disease pathogens. As for black foot disease, the causal agent Cylindrocarpon macrodidymum was isolated from the roots of 26 weed species belonging to 15 different families. As regards Petri disease, one isolate of Phaeomoniella chlamydospora was obtained from the xylem vessels of Convolvulus arvensis and three isolates of Cadophora luteoolivacea were obtained from Bidens subalternans, Plantago coronopus and Sonchus oleraceus. The fungi were inoculated in grapevine plants and typical symptoms of the diseases were verified, indicating that the host weeds act as alternative hosts for black foot and Petri disease pathogens and influence the epidemiology of these diseases.

In the current study, some vineyard weeds showed symptoms of rust, necrotic spots, holes, burned tips and dry branches but no symptoms of Petri disease, as shown in grapevine, such as reduced vegetative vigor, foliage with internerval chlorosis and necrotic margins, premature defoliation, wilting and dieback $(5,30,36)$.

Some vineyard weeds showed reddening and darkening in the xylem vessels, but none of them showed the classic symptoms of Petri disease reported for grapevines such as black spots and black streaking, tyloses and black gums $(5,36)$. In a study conducted by Agustí-Brisach et al. (2) in Spain, the xylem vessels of vineyard weeds did not present any symptoms, but Cadophora luteo-olivacea and $P$. chlamydospora were isolated from these tissues. Weeds that were completely asymptomatic but presented the phytopathogen have been reported in other studies (26). Whiting et al. (40) reported that P. chlamydospora and Phaeoacremonium spp. may act as endophytes or cause latent infections in the vine tissue, and the symptoms appear in stressed plants. Aroca et al. (6) detected mother plants of grapevine rootstocks infected with Petri disease but without any foliar symptoms. The data obtained in the current study and in other reports reinforce the need of new search for P. chlamydospora in vineyard weeds in Brazil,
Table 1. Families and species of vineyard weeds found in the phytosociological survey for diagnosis of the fungus Phaeomoniella chlamydospora.

\begin{tabular}{|c|c|c|c|c|c|}
\hline \multirow[t]{2}{*}{ Family } & \multirow[t]{2}{*}{ Species } & \multicolumn{4}{|c|}{ Locality } \\
\hline & & 1 & 2 & 3 & 4 \\
\hline \multirow[t]{10}{*}{ Asteraceae } & Parthenium hysterophorus & $\bullet$ & $\bullet$ & & $\cdot$ \\
\hline & Galinsoga parviflora & • & & - & \\
\hline & Gnaphalium spicatum & • & & & \\
\hline & Bidens pilosa & • & - & & • \\
\hline & Acanthospermum hispidum & • & & & \\
\hline & Conyza bonariensis & • & & • & $\bullet$ \\
\hline & Sonchus oleraceus & • & & & \\
\hline & Emilia fosbergii & • & - & - & $\bullet$ \\
\hline & Gamochaeta coarctata & • & & & \\
\hline & Ageratum conyzoides & - & & - & \\
\hline \multirow[t]{8}{*}{ Poaceae } & Urochloa decumbens & $\bullet$ & & & \\
\hline & Роа аппиа & - & & & \\
\hline & Cenchrus echinatus & & - & & \\
\hline & Eleusina indica & • & & - & \\
\hline & Cynodon dactylon & • & • & • & \\
\hline & Digitaria insularis & • & • & & $\bullet$ \\
\hline & Digitaria sanguinalis & • & & & \\
\hline & Digitaria horizontalis & $\bullet$ & & & $\bullet$ \\
\hline \multirow[t]{5}{*}{ Convolvulaceae } & Ipomoea triloba & $\bullet$ & $\bullet$ & & \\
\hline & Ipomoea purpurea & • & & & \\
\hline & Ipomoea hederifolia & • & & & \\
\hline & Ipomoea nil & • & & & \\
\hline & Dichondra microcalyx & $\cdot$ & & & \\
\hline \multirow[t]{3}{*}{ Euphorbiaceae } & Chamaesyce hyssopifolia & $\bullet$ & & & \\
\hline & Chamaesyce hirta & - & - & $\bullet$ & \\
\hline & Euphorbia heterophylla & - & - & & $\bullet$ \\
\hline \multirow[t]{3}{*}{ Malvaceae } & Sida rhombifolia & $\bullet$ & & & \\
\hline & Malvastrum coromandelianum & $\bullet$ & & & \\
\hline & Melochia pyramidata & $\bullet$ & & & \\
\hline \multirow[t]{3}{*}{ Amaranthaceae } & Amaranthus deflexus & $\cdot$ & & & \\
\hline & Amaranthus viridis & $\bullet$ & & & $\bullet$ \\
\hline & Alternanthera tenella & & & & $\cdot$ \\
\hline \multirow[t]{2}{*}{ Fabaceae } & Dolichos lablab & - & & & \\
\hline & Aeschynomene denticulata & $\bullet$ & & & \\
\hline \multirow[t]{2}{*}{ Rubiaceae } & Spermacoce latifolia & $\bullet$ & & & \\
\hline & Richardia brasiliensis & $\cdot$ & & - & \\
\hline \multirow[t]{2}{*}{ Portulacaceae } & Portulaca oleraceae & $\cdot$ & & $\cdot$ & \\
\hline & Talinum paniculatum & & $\bullet$ & & \\
\hline Oxalidaceae & Oxalis latifolia & $\cdot$ & & $\cdot$ & $\cdot$ \\
\hline Commelinaceae & Commelina benghalensis & $\bullet$ & $\bullet$ & $\bullet$ & $\bullet$ \\
\hline Cyperaceae & Cyperus rotundus & $\bullet$ & $\bullet$ & $\bullet$ & \\
\hline Brassicaceae & Lepidium virginicum & $\bullet$ & & & $\bullet$ \\
\hline Lamiaceae & Leonurus sibiriceus & $\cdot$ & & & \\
\hline Lythraceae & Cuphea calophylla & $\bullet$ & & & \\
\hline Phyllantaceae & Phyllanthus tenellus & $\cdot$ & - & - & \\
\hline Talinaceae & Talinum triangulare & & & & \\
\hline
\end{tabular}

Localities: 1 - Commercial vineyard fields of 'Niagara Rosada' variety in São Paulo State; 2 - Seedlings production field of the Coordination of Integral Technical Assistance, in São Bento de Sapucaí - São Paulo State; 3 - Experimental area at the Agricultural Research Company of Minas Gerais (EPAMIG), in Caldas - Minas Gerais State; and 4 - Grapevine rootstock germplasm, at the Agronomic Institute of Campinas (IAC), in Jundiaí - São Paulo State. 
even in asymptomatic weeds.

No vineyard weed was found with $P$. chlamydospora in the current study (Table 01), which did not allow defining whether the conventional or the molecular method is the best method to diagnose the fungus in these plants. Complicating factors for the diagnosis of Petri disease pathogens inside grapevines sometimes include the absence of symptoms (40) and the low concentration or incidence of the fungus in the tissue (18). Molecular diagnosis is efficient to solve these complicating factors (1), probably constituting the best tool to detect Petri disease pathogens in vineyard weeds. Diagnostic techniques have been compared for other pathosystems, and the potential of molecular diagnosis to detect phytopathogens in latent infections has been highlighted. Using molecular diagnosis, Urashima \& Zanaglia (39) detected the phytobacterium Xanthomonas albilineans in sugarcane internodes showing three different symptoms: latent, chronic and acute. In contrast, the conventional diagnostic method using Wilbrink's culture medium was not efficient to detect $X$. albilineans, especially in internodes with latent symptom.

In Brazil, the black foot disease was detected infecting grapevines only in the state of Rio Grande do Sul (20), but no infection by the fungus $C$. luteo-olivacea has been detected so far. These fungi have been reported infecting grapevines in other countries $(25,36)$. In Spain, Cylindrocarpon spp. and C. luteo-olivacea have also been detected in the vineyard weeds Sonchus oleraceus and Portulaca oleracea, for example (2). The vineyard weeds $S$. oleraceus and $P$. oleracea occur in Brazil (Table 1). If Cylindrocarpon spp. and C. luteo-olivacea become common pathogens of grapevines in Brazil, monitoring of the vineyard weeds $S$. oleraceus and $P$. oleracea is suggested since they are potential alternative hosts for those pathogens.

The vineyard weed Convolvulus arvensis was detected in Spain and Portugal. In Spain, the fungus P. chlamydospora was found infecting C. arvensis $(2,28)$. In our study, $C$. arvensis was not detected in the different vineyards or related fields. This weed was accidentally introduced into Brazil (37) and therefore should be monitored in vineyards because the fungus $P$. chlamydospora has been often found in grapevines $(3,10,20)$.

This was the first phytosociological survey of vineyard weeds in Brazil searching for plants with the fungus P. chlamydospora. No vineyard weed was found infected with the fungus $P$. chlamydospora, suggesting that Petri disease occurs only in grapevines. Therefore, the focus of Petri disease control in Brazil should be on grapevines. Meanwhile, the management of vineyard weeds should be recommended for other reasons such as competition for water, light and nutrients (28, $31,34)$.

Considering all surveyed fields, forty-six weed species were detected in 17 families, especially Asteraceae and Poaceae, which grouped the largest number of species each.

The fungus $P$. chlamydospora was not detected based on conventional and molecular diagnosis in any vineyard weed species sampled in the survey.

\section{ACKNOWLEGMENTS}

The authors thank the City Hall of Louveira, São Paulo State Brazil, especially the Director of Agriculture, Agricultural Engineer Daniel Fernando Miqueletto, for the financial support given to the current study (PSAA 494/2016).

The authors also express their thanks to those responsible for the visited areas, who kindly collaborated to the survey.

\section{REFERENCES}

1. Abreo, E.; Martínez, S.; Bettucci, L.; Lupo, S. Phaeomoniella chlamydospo$\mathrm{ra}$ and Phaeoacremonium spp. in grapevines from Uruguay. Phytopathologia Mediterranea, Bologna, v. 50, p. S77-S85, 2011.

2. Agustí-Brisach, C.; Gramaje, D.; Léon, M.; García-Jiménez, J.; Armengol, J. Evaluation of vineyard weeds as potential hosts of black-foot and Petri disease pathogens. Plant Disease, Saint Paul, v. 95, p. 803-810, 2011.

3. Almança, M.A.K.; Abreu, C.M.; Scopel, F.B.; Benedetti, M.; Halleen, F.; Cavalcanti, F.R. Evidências morfológicas da ocorrência de Phaeomoniella chlamydospora em videiras no estado do Rio Grande do Sul. Bento Gonçalves: Embrapa Uva e Vinho, 2013. 5 p. (Embrapa Uva e Vinho. Comunicado Técnico 134).

4. Amorim, L. Sobrevivência do inóculo. In: Bergamin Filho, A.; Kimati, H.; Amorim, L. (Eds.) Manual de Fitopatologia. v.1: Princípios e Conceitos. São Paulo: Agronômica Ceres. 1995. p. 246-267.

5. Aroca, Á.; Raposo, R. Pathogenicity of Phaeoacremonium species on grapevines. Journal of Phytopathology, Berlin, v. 157, p. 413-419, 2009.

6. Aroca, Á.; Gramaje, D.; Armengol, J.; García-Jiménez, J.; Raposo, R. Evaluation of the grapevine nursey propagation process as a source of Phaeoacremonium spp. and Phaeomoniella chlamydospora and occurrence of trunk disease pathogens in rootstock mother vines in Spain. European Journal of Plant Pathology, Dordrecht, v. 126, p. 165-174, 2010 .

7. Braun-Blanquet, J. Fitosociología: Bases para el estudio de las comunidades vegetales. 3rd ed. Madrid: H. Blume, 1979. $820 \mathrm{p}$.

8. Brioso, P.S.T.; Pozzer, L.; Montano, H.G.; Pimentel, J.P. Uso atual e futuro da biologia molecular na fitopatologia. Parte I - aplicações em fitopatógenos e vetor. RAPP, Passo Fundo, v. 9, p. 79-118, 2001.

9. Chaves, A.L.R.; Braun, M.R.; Eiras, M.; Colariccio, A.; Galleti, S.R. Erigon bonariensis: hospedeira alternativa do lettuce mosaic vírus no Brasil. Fitopatologia Brasileira, Brasília, v. 28, p. 307-311, 2003.

10. Correia, K.C.; Câmara, M.P.S.; Barbosa, M.A.G.; Sales Jr., R.; Agustí-Brisach, C.; Gramaje, D.; León, M.; García-Jiménez, J.; Abad-Campos, P.; Armengol, J.; Michereff, S.J. Fungal trunk pathogens associated with table grape decline in Northeastern Brazil. Phytopathologia Mediterranea, Bologna, v. 52, p. 380-387, 2013.

11. Crous, P.W.; Gams, W. Phaeomoniella chlamydospora gen. et comb. nov., a causal organism of Petri grapevine decline and esca. Phytopathologia Mediterranea, Bologna, v. 39, p. 112-118, 2000.

12. De Matheus \& Silva, L.F. De celeiro a cenário: Vitivinicultura e turismo na serra gaúcha. GEOUSP - Espaço e Tempo, São Paulo, p. 107-125, 2009.

13. Dissanayake, N.; Hoy, J.W.; Griffin, J.L. Weed hosts of the sugarcane root rot pathogen, Pythium arrhenomanes. Plant Disease, Saint Paul, v. 81, p. 587- 591, 1997

14. Doyle, J.J.; Doyle, J.L. A rapid DNA isolation procedure for small quantities of fresh leaf tissue. Phytochemical Bulletin, Sussex, v. 19, p. 11-15, 1987.

15. Dujmović-Purgar, D.; Hulina, N. Vineyard weed flora in the Jastrebarsko área (NW Croatia). Acta Botanica Croatica, Zagreb, v. 63, p. 113-123, 2004.

16. Edwards, J.; Pascoe, I. Occurrence of Phaeomoniella chlamydospora and Phaeoacremonium aleophilum associated with Petri disease and esca in Australian grapevines. Australasian Plant Pathology, Clayton, v. 33, p. 273-279, 2004.

17. Ferreira, A.B.M.; Leite, L.G.; Harakava, R.; Padovani, C.R.; Bueno, C.J. Incidência da doença de Petri na videira 'Niagara Rosada' no estado de São Paulo - Brasil. Summa Phytopathologica, Botucatu, v. 43, p. 124132, 2017.

18. Fourie, P.H.; Halleen, F. Investigation on the occurrence of Phaeomoniella chlamydospora in canes of rootstock mother vines. Australasian Plant Pathology, Clayton, v. 31, p. 425-426, 2002.

19. Fourie, P.; Halleen, F. Occurrence of grapevine trunk disease pathogens in rootstock mother vines. Australasian Plant Pathology, Clayton, v. 31, p. 425-426, 2004.

20. Garrido, L.R.; Sônego, O.R.; Gomes, V.N. Fungos Associados com o Dee clínio e Morte de Videiras no Estado do Rio Grande do Sul. Fitopatologia Brasileira, Brasília, v. 29, p. 322-324, 2004.

21. Gatica, M.; Cesari, C.; Magnin, S.; Dupont, J. Phaeoacremonium species and Phaeomoniella chlamydospora in vines showing hoja de malvon and 
young vine decline symptoms in Argentina. Phytopathologia Mediterranea, Bologna, v. 40, p. S317-S324, 2001.

22. Gramaje, D.; García-Jiménez, J.; Armengol, J. Grapevine rootstock susceptibility to fungi associated with Petri disease and esca under field conditions. American Journal of Enology and Viticulture, Davis, v. 61, p. 512-520, 2010.

23. Gramaje, D.; Mostert, L.; Groenewald, J.Z.; Crous, P.W. Phaeoacremonium: from esca disease to phaeohyphomycosis. Fungal Biology, Oxford, v. 119, p. 759-783, 2015.

24. Guarro, J.; Nucci, M.; Akiti, T.; Gené, J.; Cano, J.; Barreiro, M.D.C.; Aguilar, C. Phialemonium fungemia: two documented nosocomial cases. Journal of Clinical Microbiology, Washington, v. 37, p. 2493-2497, 1999.

25. Halleen, F.; Mostert, L.; Crous, P.W. Pathogenicity testing of lesser-ke nown vascular fungi of grapevines. Australasian Plant Pathology, Clayton, v. 36, p. 277-285, 2007.

26. Hartman, G.L.; Manandhar, J.B.; Sinclair, J.B. Incidence of Colletotrichum spp. on soybeans and weeds in llinois and pathogenicity of Colletotrichum truncatum. Plant Disease, Saint Paul, v. 70, p. 780-782, 1986.

27. Mello, L.M.R. Vitivinicultura Brasileira: Panorama 2012. Bento Gonçaves: Embrapa Uva e Vinho, 2013. 5 p. (Comunicado Técnico 137).

28. Monteiro, A.; Caetano, F.; Vasconcelos, T.; Lopes, C.M. Vineyard weed community dynamics in the Dão winegrowing region. Ciência e Técnica Vitivinicola, Runa, v. 27, p. 73-82, 2012.

29. Mostert, L.; Halleen, F.; Fourie, P.; Crous, P.W. A review of Phaeoacremonium species involved in Petri disease and esca of Grapevines. Phytopathologia Mediterranea, Bologna, v. 45, p. 12-29, 2006.

30. Mugnai, L.; Graniti, A.; Surico, G. Esca (black measles) and brown wood-streaking two old and elusive diseases of grapevine. Plant Disease, Saint Paul, v. 83, p. 404-417, 1999.
31. Paulo, E.M.; Fujiwara, M.; Terra, M.M.; Martins, F.P.; Pires, E.J.P. Controle químico e cultural das plantas daninhas na videira 'Niagara Rosada'. Bragantia, Campinas, v. 56, p. 135-143, 1997.

32. Perdomo, H.; García, D.; Gené Cano, J.J.; Sutton, D.A.; Summerbell, R.; Guarro, J. Phialemoniopsis, a new genus of Sordariomycetes, and new species of Phialemonium and Lecythophora. Mycologia, New York, v. 105, p. 398-421, 2013.

33. Pinto, P.S.G.C. Doença de Petri da Videira: Avaliação da eficácia de fungicidas na proteção de feridas de poda. 2010. 69 p. Dissertação (Mestrado em Engenharia Agronómica) - Instituto Superior de Agronomia / Universidade Técnica de Lisboa, Lisboa.

34. Pitelli, R.A. Interferência de plantas daninhas em culturas agrícolas. Informe Agropecuário, Belo Horizonte, v. 120, p. 16-27, 1985.

35. Ridgway, H.J.; Steyaert, J.M.; Pottinger, B.M.; Carpenter, M.; Nicol, D.; STEWARD, A. Development of an isolate-specific marker for tracking Phaeomoniella chlamydospora infection in grapevines. Mycologia, New York, v. 97, p. 1093-1101, 2005.

36. Scheck, H.J.; Vasquez, S.J.; Fogle, D.; Gubler, W.D. Grape growers report losses to black-foot and grapevine decline. California Agriculture, Oakland, v. 52, p. 19-23, 1998.

37. Schneider, A.A. A Flora naturalizada no estado do Rio Grande do Sul, Brasil: Herbáceas subespontâneas. Biociências, Porto Alegre, v. 5, p. 257-268, 2007.

38. Souza, J.S.I. Uvas para o Brasil. 2 ed. Piracicaba: Fealq. 1996. 791 p.

39. Urashima, A.S.; Zavaglia, A.C. Comparação de dois métodos diagnósg ticos de escaldadura-das-folhas (Xanthomonas albilineans) da canade-açúcar. Summa Phytopathologica, Botucatu, v. 38, p. 155-158, 2012.

40. Whiting, E.C.; Khan, A.; Gubler, W.D. Effect of temperature and water potential on survival and mycelial growth of Phaeomoniella chlamydospora and Phaeoacremonium spp. Plant Disease, Saint Paul, v. 85, p. 195-201, 2001 